REVIEW ARTICLE

\author{
Maan Singh Sidhu and Ingar Olsen
}

\title{
S-layers of Bacillus species
}

\author{
Author for correspondence: Ingar Olsen. Tel: $+4722856046 / 52$. Fax: +4722857867 . \\ e-mail: ingaro@odont.uio.no
}

Department of Oral Biology, Dental Faculty, University of Oslo, POB 1052, Blindern 0316, Oslo, Norway

Keywords: Bacillus species, S-layers, surface layers, crystalline proteins

\section{Overview}

S-layers are regular crystalline surface layers in prokaryotic organisms composed of protein or glycoprotein subunits (Beveridge, 1994; Sleytr et al., 1993, 1988a, 1986b; Sleytr \& Messner, 1992, 1988a, b, 1983; Beveridge \& Graham, 1991; Hovmöller et al., 1988; Koval, 1988; Baumeister \& Engelhardt, 1987). Most of the presently known S-layers are composed of identical proteins or glycoproteins of molecular mass $30-220 \mathrm{kDa}$ (Sleytr et al., 1994; Messner \& Sleytr, 1992). Such layers have been recognized as common features of both prokaryote domains (archaeobacteria and eubacteria). S-layers can be associated with quite different cell envelope structures, such as peptidoglycan, pseudomurein or components of the outer plasma membrane (Fig. 1). In Gram-negative eubacteria (e.g. Aeromonas salmonicida), S-layers are associated with the outer membrane and in some archaeobacteria (e.g. Methanococcus jannaschii), S-layers are the sole cell wall structure and therefore associated only with the plasma membrane. The subunits are linked together and also to the underlying cell envelope layers by non-covalent forces (Messner \& Sleytr, 1992; Beveridge \& Graham, 1991; König, 1988). S-layers can be exclusive wall components in cell envelope structures of Gram-negative archaeobacteria (Sleytr \& Messner, 1992). Most of the presently known S-layers are composed of a single (glyco)protein species endowed with the ability to assemble into two-dimensional arrays on a supporting envelope layer, and they are characterized by defined symmetry and pores of uniform size (Hovmöller et al., 1988; Sleytr \& Messner, 1983). When S-layers are compared with heteroporous materials, they can be considered as an ideal matrix (e.g. Bacillus and Clostridium species), because functional groups are not only aligned in high density on the S-layer surface but also show identical position and orientation on each protomer (Sára et al., 1993a, b). On the outer surface of Slayers from most members of the family Bacillaceae, an equimolar amount of amino and carboxyl groups is present, and in the case of S-layer glycoproteins there is also a high number of surface-located hydroxyl groups available (Sleytr et al., 1994). Comparative analysis of amino acid and genetic studies on S-layers showed that crystalline arrays are usually composed of weakly acidic proteins at neutral $\mathrm{pH}$. The content of hydrophobic amino acids is generally high and the cysteine or methionine content low (Sleytr et al., 1993). S-layers are porous crystalline membranes $5-15 \mathrm{~nm}$ thick (Sleytr et al., 1994), which completely cover the cell surface and can provide micro-organisms with a selective advantage by functioning as protective coats, molecular sieves, molecule and ion traps, and structures involved in cell adhesion and surface recognition (Sleytr et al., 1993; Messner \& Sleytr, 1992; Hovmöller et al., 1988; Sléytr \& Messner, 1983). S-layers were identified as contributing to virulence when present as a structural component of pathogens and possess great potential for various biotechnological, biomedical and non-biomedical applications (Sleytr et al., 1993).

The genus Bacillus consists of facultatively anaerobic Gram-positive, spore-forming rod-shaped bacteria and is a principal member of the family Bacillaceae. Most Bacillus species are saprophytic, using a range of naturally occurring substrates (Maiden et al., 1992). Some species are associated with human and animal infections and food spoilage. A number of major pathogens are encountered among the many recognized Bacillus species. B. anthracis causes anthrax in animals and humans (Thorne, 1993). B. cereus is a major cause of food poisoning (Drobniewski, 1993; Beecher \& Macmillan, 1991). Other Bacillus species may cause serious infections such as bacteraemia, meningitis, endocarditis and eye infections as opportunists, often in immunocompromised patients. Bacillus species are also isolated sporadically from pockets associated with marginal periodontitis and implantitis, and from the root canal (unpublished observations). Some Bacillus species such as B. thuringiensis are insect pathogens and are used as 'biological insecticides' (Aronson, 1993). Only sporadically have reports on the existence of Slayers in Bacillus species appeared in the literature. This article gives a review of the subject, together with information on aspects such as their structure, isolation, synthesis, functions and genetics. 
(a)

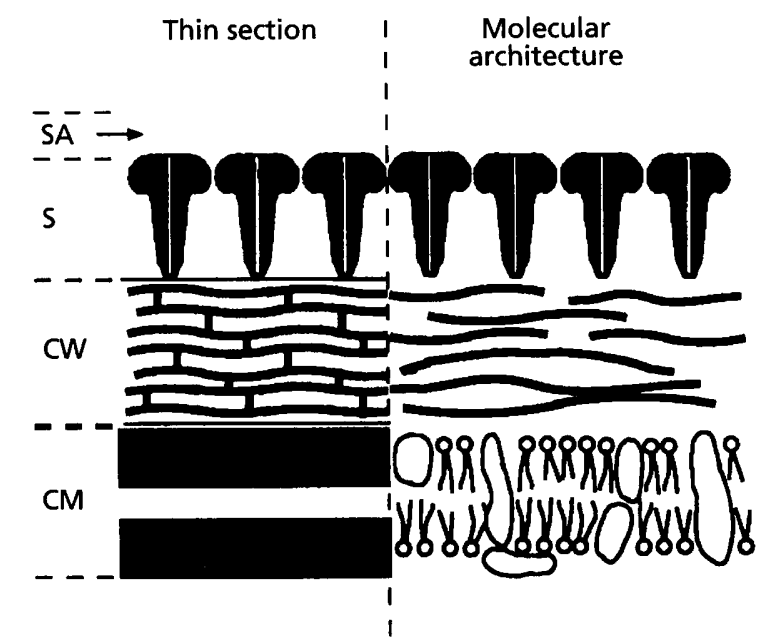

(b)

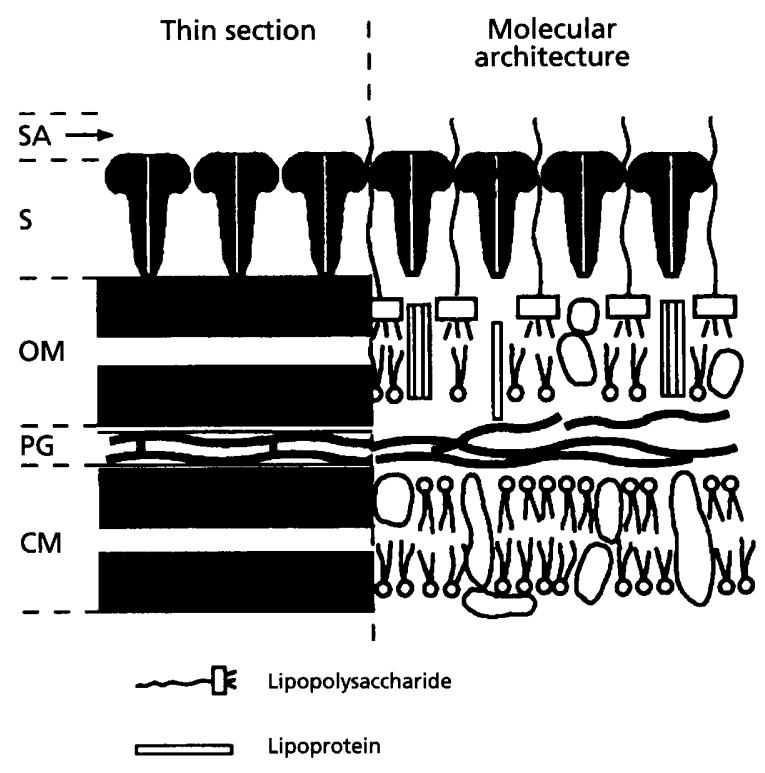

$0<$ Membrane lipid

Pore protein

Peptidoglycan or pseudomurein

Fig. 1. Schematic illustration of major classes of prokaryotic cell envelopes containing crystalline surface layers (S-layers). Left, thin-section profile as revealed by electron microscopy; right, molecular architecture showing major components. (a) Gram-positive cell envelope as observed in eubacteria and archaeobacteria (containing peptidoglycan or pseudomurein, respectively); (b) Gram-negative cell envelope as observed in eubacteria. S, crystalline surface layer; SA, location of possible additional S-layer; $\mathrm{CW}$, rigid cell wall layer composed primarily of peptidoglycan in eubacteria or pseudomurein in archaeobacteria; PG, peptidoglycan layer; CM, cytoplasmic membrane; OM, outer membrane. (Modified from Sleytr \& Messner, 1992.)

\section{Crystalline surface layers in Bacillus species}

S-layers have been found in several Bacillus species (Doyle et al., 1986; Abe \& Kimoto, 1984; Messner et al., 1984; Abe et al., 1983; Howard \& Tipper, 1973; Nermut \& Murray, 1967; Goundry et al., 1967) and different types are listed in Table 1 . The S-layer of B. sphaericus NCTC 9602, which is composed of an acidic glycoprotein containing a single homogeneous peptide chain, and that of $B$. brevis 47 are the best studied in the Bacillaceae. B. brevis 47 has a three-layered wall between 27 and $29 \mathrm{~nm}$ thick in which the thin innermost layer of peptidoglycan and teichoic acid is covered by a hexagonal array of subunits (Udaka et al., 1989; Tsuboi et al., 1982). Pure S-layer preparations reveal more than one band on SDS-PAGE gels. This explains the presence of two closely associated S-layers composed of different subunit species (Abe et al., 1983; Tsuboi et al., 1982). B. brevis HPD31 contains one major protein, with an approximate molecular mass of $135 \mathrm{kDa}$, in its cell wall (Gruber et al., 1988), while the two S-layer wall proteins of B. brevis 47 are 115 and $104 \mathrm{kDa}$ in size (Daugulis et al., 1993; Tsuboi et al., 1982; Yamada et al., 1981). A similar multilayered cell wall structure was also observed in S-layer-deficient bacteria, such as Bacillus sp. CIP 76-111, B. polymyxa and in Clostridium nigrificans (Leduc et al., 1977; Nermut \& Murray, 1967). Two S- layer proteins are further reported in B. macroides strain D (Holt \& Leadbetter, 1969), B. brevis CCM 1463 (Sára et al., 1990) and B. brevis HPO33 (Gruber et al., 1988; Yamada et al., 1981). The two S-layers exhibit uniform pore morphologies, while individual lattices can display more than one type of pore (Hovmöller et al., 1988; Sleytr et al., 1988a). The purified S-layer from $B$. stearothermophilus NRS strain 2004/3a and Desulfotomaculum nigrificans strain NCIB 8395 produces more than one band on SDS-PAGE, and this can be explained by variation in the degree of glycosylation rather than by differences in the polypeptide portions of the subunits (Sleytr et al., 1986b). The S-layer of B. sphaericus P-1 has square (p4) symmetry, a lattice constant of $13 \mathrm{~nm}$, a thickness of $8 \mathrm{~nm}$, and its structure is similar to that of the closely related species Sporosarcina ureae. Also, its rough surface layer faces towards the bacterial cell wall (Engelhardt et al., 1986). According to Aebi et al. (1973), the T-layer (S-layer) structure can be divided into three domains : a major domain, a minor domain and an arm. The S-layer of $B$. sphaericus P-1 has minor and arm domains (Aebi et al., 1973) which form a basket-like structure raised away from the cytoplasm, and such a feature seems to be characteristic of most S-layers (Baumeister et al., 1986). The basket-like structure of the S-layer is highly perforated having a channel diameter less than $3 \mathrm{~nm}$, thus suggesting that the S-layer 
functions as a selective molecular barrier (Stewart et al., 1986; Stewart \& Beveridge, 1980). Gruber \& Sleytr (1988) observed distinct insertion bands for the S-layer in B. stearothermophilus, which spirals around the cylindrical surface at a pitch angle related to the orientation of the lattice vectors of the arrays. Little or no S-layer was inserted into pre-existing S-layer at old cell poles, whereas new cell poles were covered with new proteins.

An interesting feature of many archaeobacteria and certain Gram-positive and Gram-negative eubacteria is the ability to glycosylate their S-layer proteins (Messner \& Sleytr, 1991). The first glycoprotein S-layer was detected in B. stearothermophilus (Messner \& Sleytr, 1991), containing two glycan substituents, an asparagine-linked rhamnan and an oligosaccharide having a diaminouronic acid (Messner et al., 1987; Christian et al., 1986). Studies of the S-layer glycoproteins from different Bacillus and Clostridium species showed that the composition of the glycans is a strain-specific feature. More than one type of carbohydrate residue may be linked to S-layer proteins and the chain length can vary from a few sugars up to approximately 150 monosaccharide residues (Messner \& Sleytr, 1992, 1991). The glycan chain can be linked to the protein moiety by $\mathrm{N}$ - or O-glycosidic linkages (Sleytr et al., 1994). Glycosylated S-layers with varying carbohydrate contents have been detected in a number of strains from the Bacillaceae such as B. sphaericus (Lewis et al., 1987; Word et al., 1983), B. stearothermophilus (Messner et al., 1987; Küpcü et al., 1984) and D. nigrificans (Sleytr et al., 1986b). Glycosylation of the S-layer proteins may be of crucial importance in protecting the cells from their own (or foreign) exoproteases (Sleytr \& Messner, 1983). Protein glycosylation is a costly process to the organisms in terms of energy and materials, because the carbohydrate moieties are secondary gene products, necessitating the synthesis of specific enzymes (Sleytr et al., 1986b). Preliminary taxonomic characterization of Bacillus sp. L420-91 revealed that the S-layer glycoprotein of this organism is closely related to that of B. aneurinolyticus, having $\mathrm{p} 4$ symmetry with molecular mass $109 \mathrm{kDa}$. The total carbohydrate content of the purified glycoprotein was approximately $3.5 \%$ (Kosma et al., 1995).

\section{Preparation and isolation of S-layers}

S-layers of different bacteria may vary considerably with respect to their resistance to disruption into monomeric subunits, and a wide range of methods has been applied for their isolation and purification. The subunits of most S-layers interact with each other and with the supporting envelope layer through non-covalent forces. In Grampositive bacteria a complete disintegration of the layer into monomers can be achieved by treatment of intact cells or walls with high concentrations of $\mathrm{H}$-bondbreaking agents such as urea, guanidine hydrochloride (Sára \& Sleytr, 1994; Kuen et al., 1994; Sleytr et al., 1986a) or SDS (Kotiranta et al., 1995), or by lowering or raising the $\mathrm{pH}$ value (Sleytr, 1976). Procedures used for extracting S-layers from Gram-positive bacteria are summarized in Table 2. S-layers from Gram-negative bacteria frequently disrupt upon application of metal chelating agents such as EDTA, EGTA, cation substituents such as $\mathrm{Na}^{+}$to replace $\mathrm{Ca}^{2+}$, or $\mathrm{pH}$ changes such as a reduction to $\mathrm{pH}<4.0$ (Sleytr \& Messner, 1992, 1988a, 1983; Sleytr et al., 1986a). In the case of B. stearothermophilus DSM 2358, S-layer fragments were released during preparation of spheroplasts by treatment of whole cells with lysozyme (Egelseer et al., 1995). Slayers are generally isolated from cell envelope fragments prepared by mechanical cell disruption using, for example, sonication, French pressure-cells, cell homogenization with glass beads or, in special cases, freezethawing. Treatment with nucleases may be necessary before final isolation of the cell wall by differential centrifugation (Sprott et al., 1994). The cell-wall preparation of B. stearothermophilus (Egelseer et al., 1995; Breitwieser et al., 1992) and B. brevis HPD31 (Ebisu et al., 1990), was obtained by treatment with detergents such as Triton X-100 to selectively solubilize adherent cytoplasmic membrane fragments contaminating the cell walls (Breitwieser et al., 1992; Beveridge, 1979; Sleytr \& Glauert, 1976). Removal of the solubilizing agent by dialysis or dilution allowed the S-layer to be reassembled into two-dimensional crystalline lattices identical to those observed in intact cells (Jaenicke et al., 1985). From extraction and disintegration experiments it can be concluded that the bonds holding the S-layer subunits together are stronger than those binding the crystalline array to the supporting envelope layer (Beveridge, 1994). Studies of S-layer-carrying organisms, particularly members of the family Bacillaceae, show that an inner S-layer can be formed on the peptidoglycan of intact cells when the plasma membrane becomes detached during plasmolysis or autolysis (Sleytr, 1978), for example in B. polymyxa (Nermut \& Murray, 1967). There are some indications that S-layers of some archaeobacteria are stabilized by covalent bonds between adjacent subunits (Sleytr et al., 1993).

\section{Synthesis of S-layers}

S-layer protein can constitute up to $15 \%$ of the total protein of a cell in the exponential growth phase (Sleytr et al., 1993). Under artificial conditions, when bacteria are cultivated in laboratory media, S-layer-deficient mutants can outgrow the wild-type strain (Koval \& Murray, 1986). S-layers are frequently lost upon prolonged cultivation under laboratory conditions indicating that they provide the organisms with a selective advantage in their natural and competitive habitats (Sleytr, 1978). Although many S-layer proteins are synthesized as secretory precursors, mature proteins are usually not liberated into the surrounding medium but are assembled into regular arrays on the cell surface (Sleytr \& Messner, 1992; Sleytr et al., 1988b). An exception is the case of certain strains of B. brevis which, dependent on the growth conditions, produce excess amounts of S-layer material. This is shed into the medium (Sleytr \& Messner, 1992). Only a few organisms 
Table 1. Types of S-layer lattices in Bacillus species

Modified from Sleytr et al. (1996, 1988b); Messner \& Sleytr (1992); Sleytr \& Messner (1983).

\begin{tabular}{|c|c|c|c|c|c|}
\hline Species & Strain & $\begin{array}{c}\text { Lattice } \\
\text { symmetry* }\end{array}$ & $\begin{array}{l}\text { Spacing } \\
(\mathbf{n m})\end{array}$ & $\begin{array}{l}\text { Molecular } \\
\text { mass } \\
(\mathrm{kDa})\end{array}$ & Reference \\
\hline \multirow[t]{2}{*}{ B. alvei† } & CCM 2051 & $\mathrm{p} 2$ & $10 \cdot 0-7 \cdot 9$ & $127 / 128 / 147$ & $\begin{array}{l}\text { Altman et al. } \\
\text { (1991); Sára et al. } \\
(1990)\end{array}$ \\
\hline & 183 & p6 & $10-12$ & ND & Yoshii (1966) \\
\hline \multirow{2}{*}{$\begin{array}{l}\text { B. aneurinolyticus } \\
\text { (type I) }\end{array}$} & 7 strains & $\mathrm{p} 4$ & $9 \cdot 6$ & 129 & Abe \& Kimoto (1984) \\
\hline & 13 strains & $\mathrm{p} 4$ & $9 \cdot 6$ & 114 & Abe $\&$ Kimoto $(1984)$ \\
\hline \multirow[t]{2}{*}{ B. anthracis } & - & p6 & $7-10$ & 94 & $\begin{array}{l}\text { Toumelin et al. (1995); } \\
\text { Farchaus et al. (1995); Holt \& } \\
\text { Leadbetter (1969); Gerhardt } \\
(1967)\end{array}$ \\
\hline & & $\mathrm{p} 1$ & & & Doyle et al. (1986) \\
\hline \multirow[t]{10}{*}{ B. brevis } & HPD31 & p6 & $17 \cdot 4-18 \cdot 4$ & $110-150$ & $\begin{array}{l}\text { Ebisu et al. (1990); Tsuboi et } \\
\text { al. (1988); Gruber et al. (1988) }\end{array}$ \\
\hline & CCM $1089 \ddagger$ & $\begin{array}{l}\mathrm{p} 2 \\
\mathrm{p} 6\end{array}$ & $\begin{array}{c}11 \cdot 6-8 \cdot 5 \\
16 \cdot 7\end{array}$ & $\left.\begin{array}{c}119 / 102 \\
\text { ND }\end{array}\right\}$ & $\begin{array}{l}\text { Lupas et al. }(1994) \\
\text { Sára et al. }(1990)\end{array}$ \\
\hline & - & $\mathrm{p} 4$ & ND & ND & Sára et al. (1990) \\
\hline & $47 \ddagger$ & p6 & $14 \cdot 5$ & $150\}$ & Koval (1993); Tsuboi et al. \\
\hline & - & p6 & $14 \cdot 5$ & $130\}$ & (1986, 1982); Yamada \\
\hline & $\begin{array}{l}47-57 \text { (phage- } \\
\text { resistant } \\
\text { mutant) }\end{array}$ & p6 & $14 \cdot 5$ & 150 & $\begin{array}{l}\text { Tsuboi et al. (1982); Yamada } \\
\text { et al. (1981) }\end{array}$ \\
\hline & CCM 1463‡ & $\mathrm{p} 2$ & $11 \cdot 0-8 \cdot 0$ & $102\}$ & Koval (1993); Sára et al. \\
\hline & - & p6 & $17 \cdot 0$ & $118\}$ & $(1990)$ \\
\hline & - & $\mathrm{p} 2$ & ND & ND & Sára et al. (1990) \\
\hline & S-1 & p6 & 17 & 129 & Abe et al. (1983) \\
\hline \multirow[t]{3}{*}{ B. cereus } & $599-1-95$ & p6 & ND & $97 \cdot 4$ & Authors' unpublished results \\
\hline & $600-3-95$ & p6 & ND & $97 \cdot 4$ & Authors' unpublished results \\
\hline & ATCC 4342 & $\mathrm{p} 4$ & $9 \cdot 0-10 \cdot 0$ & ND & Ellar \& Lundgren (1967) \\
\hline \multirow[t]{2}{*}{ B. circulans } & CCM 1084 & $\mathrm{p} 2$ & $9 \cdot 6-8 \cdot 0$ & 117 & Sára et al. (1990) \\
\hline & CCM 2048 & p4 & $8 \cdot 6$ & 120 & Sára et al. (1990) \\
\hline B. coagulans & E36-68 & $\mathrm{p} 2$ & $9 \cdot 4-7 \cdot 4$ & 100 & $\begin{array}{l}\text { Pum et al. (1993); Sára et al. } \\
\text { (1992); Ohnesorge et al. } \\
(1992)\end{array}$ \\
\hline B. fastidiosus & - & $\mathrm{p} 4$ & $12 \cdot 0-13 \cdot 5$ & ND & Holt \& Leadbetter (1969) \\
\hline B. licheniformis & NM105 & $\mathrm{p} 4$ & $11 \cdot 6$ & 98 & Tang et al. (1989) \\
\hline \multirow[t]{2}{*}{ B. macroides } & $\begin{array}{c}\text { Strains } A \\
\text { and } \mathrm{D} \neq\end{array}$ & $\mathrm{p} 4$ & $5 \cdot 0-6 \cdot 0$ & ND & Holt \& Leadbetter (1969) \\
\hline & - & $\mathrm{p} 4$ & $9-10$ & ND & Holt \& Leadbetter (1969) \\
\hline B. megaterium & - & $\mathrm{p} 4$ & $19 \cdot 0$ & ND & Sawatake (1966) \\
\hline \multirow[t]{2}{*}{ B. polymyxa } & CCM 1459 & $\mathrm{p} 4$ & $10 \cdot 0$ & 142 & Sára et al. (1990) \\
\hline & NCIB 4747 & $\mathrm{p}^{4}$ & $10 \cdot 0$ & ND & $\begin{array}{l}\text { Burley \& Murray (1983); Finch } \\
\text { et al. (1967); Goundry et al. } \\
\text { (1967); Nermut \& Murray } \\
\text { (1967) }\end{array}$ \\
\hline B. psychrophilus & W16A & $\mathrm{p} 4$ & $15-16$ & ND & Holt \& Leadbetter (1969) \\
\hline
\end{tabular}


Table 1. Cont.

\begin{tabular}{|c|c|c|c|c|c|}
\hline Species & Strain & $\begin{array}{c}\text { Lattice } \\
\text { symmetry* }\end{array}$ & $\begin{array}{l}\text { Spacing } \\
(\mathbf{n m})\end{array}$ & $\begin{array}{l}\text { Molecular } \\
\text { mass } \\
(\mathrm{kDa})\end{array}$ & Reference \\
\hline B. schlegelii & DSM 2000 & p4 & $9 \cdot 0$ & ND & Schenk \& Aragno (1979) \\
\hline \multirow[t]{4}{*}{ Bacillus sp. } & CIP 76-111 & p6 & $11 \cdot 0$ & 255 & Leduc et al. (1977) \\
\hline & KL8 & p6 & $9-10$ & ND & Kari et al. (1990) \\
\hline & L420-91 & p4 & ND & 109 & Kosma et al. (1995) \\
\hline & M3198 & $\mathrm{p} 2$ & $9 \cdot 5$ & $\mathrm{ND}$ & Haapasalo et al. (1988) \\
\hline \multirow[t]{8}{*}{ B. sphaericus } & $\begin{array}{l}\text { Several } \\
\text { strains }\end{array}$ & $\mathrm{p} 4$ & $13 \cdot 0$ & ND & $\begin{array}{l}\text { Sleytr \& Glauert (1975); Holt } \\
\text { \& Leadbetter (1969) }\end{array}$ \\
\hline & $\begin{array}{l}\text { Several } \\
\text { strains }\end{array}$ & ND & ND & $127-133$ & $\begin{array}{l}\text { Lewis et al. (1987); Word et al. } \\
\text { (1983) }\end{array}$ \\
\hline & NCTC 9602 & $\mathrm{p} 4$ & $13 \cdot 0$ & 142 & Hastie \& Brinton $(1979 a, b)$ \\
\hline & $9602(\mathrm{Lmw})$ & $\mathrm{p} 4$ & $13 \cdot 0$ & 120 & Hastie \& Brinton $(1979 a, b)$ \\
\hline & $\mathrm{P}-1 \$$ & $\mathrm{p} 4$ & $13 \cdot 0$ & 140 & $\begin{array}{l}\text { Lepault et al. (1986); Howard } \\
\text { et al. (1982); Howard \& } \\
\text { Tipper (1973) }\end{array}$ \\
\hline & CCM 2120 & $\mathrm{p} 4$ & $11 \cdot 2$ & 120 & Sára et al. (1990) \\
\hline & CCM 2177 & p4 & $12 \cdot 6$ & 122 & $\begin{array}{l}\text { Ohnesorge et al. (1992); Sára et } \\
\text { al. (1990) }\end{array}$ \\
\hline & 2362 & $\mathrm{p} 2$ & $\mathrm{ND}$ & 125 & Bowditch et al. (1989) \\
\hline \multirow[t]{11}{*}{ B. stearothermophilus } & 39 strains & $\mathrm{p} 6, \mathrm{p} 4, \mathrm{p} 2$ & $5 \cdot 2-17 \cdot 9$ & $83-170$ & $\begin{array}{l}\text { Messner et al. (1984); Sleytr et } \\
\text { al. (1969) }\end{array}$ \\
\hline & 4 strains & $\mathrm{p} 6, \mathrm{p} 4, \mathrm{p} 2$ & $8 \cdot 5-22 \cdot 5$ & $93-170$ & Sleytr et al. $(1986 \mathrm{~b})$ \\
\hline & PV72 & p6 & $22 \cdot 5$ & 130 & $\begin{array}{l}\text { Sára et al. (1996); Kuen et al. } \\
\text { (1994); Sára \& Sleytr (1994); } \\
\text { Gruber \& Sleytr (1988) }\end{array}$ \\
\hline & ATCC 12980 & $\mathrm{p} 2$ & ND & ND & Gruber \& Sleytr (1988) \\
\hline & $\mathrm{E} 4-65$ & $\mathrm{p} 4$ & $10 \cdot 8$ & 97 & Sleytr et al. (1986b) \\
\hline & DSM 2358 & $\mathrm{p} 2$ & ND & 98 & Egelseer et al. (1995) \\
\hline & NRS $1536 / 3 c$ & $\mathrm{p} 4$ & $13 \cdot 8$ & 120 & $\begin{array}{l}\text { Sára \& Sleytr (1994); Sára et } \\
\text { al. (1992); Sleytr et al. (1986b) }\end{array}$ \\
\hline & NRS 2004/3a & $\mathrm{p} 2$ & $11 \cdot 6-9 \cdot 4$ & $\begin{array}{c}96 ; 119 \| \\
147\|; 170\|\end{array}$ & $\begin{array}{l}\text { Sára \& Sleytr (1994); Sleytr et } \\
\text { al. (1986b) }\end{array}$ \\
\hline & $3 a / V 1$ & $\mathrm{p} 2$ & $9 \cdot 9-7 \cdot 6$ & 97 & Sára \& Sleytr (1994) \\
\hline & $3 \mathrm{c} / \mathrm{p} 2$ & p2 & $9 \cdot 9-7 \cdot 6$ & 97 & Sára \& Sleytr (1994) \\
\hline & $\mathrm{PV} 72 / \mathrm{p} 2$ & $\mathrm{p} 2$ & $9 \cdot 9-7 \cdot 6$ & 97 & Sára \& Sleytr (1994) \\
\hline B. subtilis & - & $\mathrm{p} 4$ & $7 \cdot 5$ & ND & Howatson \& Russell (1964) \\
\hline $\begin{array}{l}\text { B. thuringiensis } 4045 \\
\text { subsp. galleriae }\end{array}$ & - & $\mathrm{p} 2$ & $8 \cdot 5-7 \cdot 2$ & $91 \cdot 4$ & Luckevich \& Beveridge (1989) \\
\hline $\begin{array}{l}\text { B. thuringiensis var. } \\
\text { berliner }\end{array}$ & $\begin{array}{l}1715 \\
(\mathrm{AH} 418)\end{array}$ & p6 & ND & $66 \cdot 2-97 \cdot 4$ & Authors' unpublished results \\
\hline
\end{tabular}

ND, Not determined.

*p6, hexagonal; p4, square; p2, oblique.

† Now Paenibacillus alvei (Messner \& Sleytr, 1992).

$\ddagger$ Two S-layers.

\$Formerly Bacillus brevis P-1 (Howard \& Tipper, 1973).

$\|$ According to the periodate acid-Schiff (PAS) staining procedure, bands are glycosylated.

have been reported to shed large or small quantities of excess material into the medium as assembled S-layer fragments (Yamada et al., 1981; Sleytr \& Glauert, 1976; Thorne et al., 1976; Udaka et al., 1989; Udaka, 1976). B. brevis 47 is known to secrete $16 \mathrm{~g}$ of S-layer proteins $\mathrm{I}^{-1}$ into the medium (Wight et al., 1992), particularly on supplementation of the medium with amino acids (Sára et al., 1996). However, according to Takagi et al. (1989) 
Table 2. General isolation procedures for S-layers from Gram-positive bacteria

\begin{tabular}{|c|c|}
\hline Procedure & Reference \\
\hline Removal of peptidoglycan layer with lysozyme & $\begin{array}{l}\text { Egelseer et al. (1995); Lupas et al. (1994); Sára et al. (1992); Abe et al. } \\
\text { (1983); Beveridge (1979); Masuda \& Kawata (1979); Nermut \& } \\
\text { Murray (1967); Sleytr (1976) }\end{array}$ \\
\hline $\begin{array}{l}\text { Extraction of S-layer proteins with low concentrations of } \\
\text { chaotropic agents, e.g. } 4 \mathrm{M} / 6 \mathrm{M} \text { urea, } 1.5 \mathrm{M} \\
\text { guanidinium hydrochloride, etc. }\end{array}$ & $\begin{array}{l}\text { Takumi et al. (1991); Bowditch et al. (1989); Sleytr \& Plohberger } \\
(1980) \text {; Nermut \& Murray (1967) }\end{array}$ \\
\hline $\begin{array}{l}\text { Extraction of S-layer proteins with high concentrations of } \\
\text { chaotropic agents or detergents, e.g. } 8 \mathrm{M} \text { urea, } 5 \mathrm{M} \\
\text { guanidinium hydrochloride, } 1 \% \mathrm{SDS}, 100 \% \text { formamide } \\
\text { etc. }\end{array}$ & $\begin{array}{l}\text { Sára et al. (1996, 1992, 1990); Sára \& Sleytr (1994); Pum et al. (1993); } \\
\text { Tsuboi } \text { et al. (1989); Hastie \& Brinton (1979a); Masuda \& Kawata } \\
\text { (1979); Sleytr \& Thorne (1976); Howard \& Tipper (1973); Goundry } \\
\text { et al. (1967); Nermut \& Murray (1967) }\end{array}$ \\
\hline $\begin{array}{l}\text { Extraction of S-layer from whole cells by treatment with } \\
0.2 \mathrm{M} \text { glycine hydrochloride at } \mathrm{pH} 3.0\end{array}$ & Dooley et al. $(1988)$ \\
\hline $\begin{array}{l}\text { Extraction with chaotropic agents followed by column } \\
\text { chromatographic purification, e.g. Sepharose CL-6B in } \\
5 \mathrm{M} \text { guanidinium hydrochloride }\end{array}$ & Takumi et al. (1991); Küpcü et al. (1984) \\
\hline
\end{tabular}

B. brevis HPD31 secretes up to $30 \mathrm{~g}^{-1}$ of a protein derived from a cell-wall component under optimal growth conditions. Characteristic of most members of the family Bacillaceae is the lack of S-layer proteins in the culture supernatant during exponential growth. Only during the late exponential-early stationary phase are free S-layer sheets frequently detected (Sleytr \& Glauert, 1975). In the case of B. sphaericus, the S-layer protein is synthesized during vegetative growth (Lewis et al., 1987) and upon completion of exponential growth, there is a burst in synthesis of the $122 \mathrm{kDa}$ protein (Broadwell \& Baumann, 1986). A pool of S-layer protein must, even in a cell with no overproduction, exist either in the periplasm of Gram-negative bacteria (Beveridge \& Graham, 1991) or in the peptidoglycan network of Gram-positive bacteria.

In certain Gram-positive archaeobacteria two different types of lipid carriers are involved in the biosynthesis of cell envelope components. Undecaprenol is the common lipid carrier for pseudomurein biosynthesis, whereas dolichol is involved in the biosynthesis of the S-layer glycoproteins (Messner \& Sleytr, 1992). Synthesis of the $S$-layer glycoprotein of $B$. alvei demonstrated that the glycan biosynthesis in eubacteria is very similar to that in archaeobacteria (Hartmann et al., 1993). The rapid appearance of granular regions close to the regular Slayer lattice on the cell surface of B. stearothermophilus indicates that synthesis of original S-layer proteins by wild-type strains stops immediately on an increase in the oxygen supply (Sára et al., 1996; Sára \& Sleytr, 1994). The S-layer proteins from three different B. stearothermophilus strains revealing oblique, square or hexagonal lattice symmetry were preserved during growth in continuous culture on complex medium only under oxygen-limited conditions in which glucose was used as the sole carbon source (Sára \& Sleytr, 1994). This shows that synchronous $S$-layer protein synthesis is not a stable process in the case of $B$. stearothermophilus PV72 (Sára et al., 1996).

\section{Electron microscopy}

Unlike most other surface structures, the S-layer arrays can be unequivocally identified only by electron microscopy (EM). With EM, freeze-etching (Sleytr \& Messner, 1992) and negative staining (Beveridge, 1994, 1981) are the best methods for determining S-layer structures. Recently, high resolution three-dimensional structures of several S-layers have been obtained by transmission electron microscopy and scanning probe microscopy (both atomic force and scanning tunnelling microscopy) provided topographical details (Beveridge, 1994). Etching will expose the subunit profile because the grains of the shadowing metal such as platinum are relatively large (approximately $0.2-0.5 \mathrm{~nm}$ ). Freezeetching reveals only the general form of the alignment of the S-layer subunits around the cell. Crystal defects are often seen with this method (Sleytr \& Messner, 1988a, 1983). Negative staining is a better resolving technique and relies on the fact that heavy metal salts such as phosphotungstate and uranyl acetate (Beveridge $e t$ al., 1994; Pum et al., 1989) can enshroud subunits in an electron-dense 'glass' revealing contour and linkage of proteinaceous components. On negatively stained cells an S-layer may be seen as a thin, periodic fringe at the cell periphery. It is very difficult to determine directly cell wall-S-layer interactions in cells by EM without fixation, embedding and thin sectioning. Since this technique requires dehydration with organic solvents, correct protein conformation can be altered and organic constituents extracted. According to Pum et al. (1993), EM studies of the crystalline S-layer of $B$. coagulans E38-66 was enhanced by negative staining of the protein and protein-lipid monolayer with uranyl acetate after 
fixation with glutaraldehyde, but in the case of $B$. anthracis bacteria were adsorbed on to Formvar and carbon copper grids previously made hydrophilic by glow discharge. The thin sections were stained with uranyl acetate and lead citrate after pre- and postfixation (Sleytr et al., 1988a). Three-dimensional reconstruction of negatively stained S-layers of B. sphaericus P-1, displays a smooth and a rough surface on either side of the protein layer (Lepault et al., 1986).

\section{S-layer symmetries}

S-layers are planar arrays of identical proteinaceous or glycoproteinaceous subunits which can be aligned in unit cells of hexagonal (p6), tetragonal (p4), trimeric (p3) or oblique (p2) symmetries (Sára et al., 1996; Egelseer et al., 1995; Beveridge, 1994, 1981 ; Beveridge \& Koval, 1993; Hovmöller et al., 1988; Koval, 1988; Sleytr \& Messner, 1988a, b, 1983; Baumeister \& Engelhardt, 1987; Koval \& Murray, 1986). The morphological units of oblique, trimeric, tetragonal and hexagonal lattices consist of two, three, four and six monomers, respectively. The centre-to-centre spacing of the morphological units can range from 3 to $35 \mathrm{~nm}$ (Sleytr et al., 1994, 1993). The regularity of their arrangement makes them convenient structures for crystallographic analysis and computer image enhancement (Stewart, 1988, 1986; Baumeister \& Engelhardt, 1987). Different types of Slayer lattices in Bacillus species are summarized in Table 1 and Fig. 2. Holt \& Leadbetter (1969) and Gerhardt (1967) described a hexagonal lattice on the surface of vegetative cells of $B$. anthracis. This structure most likely represented an S-layer with $\mathrm{p} 1$ symmetry and a centre-to-centre spacing of the particle of 7-10 nm (Doyle et al., 1986). Strains of a single phenotypic and genetic species can show several distinctive lattice forms among their number as seen in B. stearothermophilus (Messner et al., 1984), and the specific properties of Slayer proteins from three different $B$. stearothermophilus strains revealed oblique, square or hexagonal symmetry (Sára \& Sleytr, 1994). According to Luckevich \&
Beveridge (1989), the B. thuringiensis S-layer is composed of linear arrays of small particles arranged with p2 symmetry.

\section{Self-assembly of S-layers}

Isolated S-layer subunits of Gram-positive and Gramnegative bacteria have the ability to recrystallize on the cell envelope fragments from which they have been removed, on those of other organisms or on untextured charged or uncharged inanimate objects (Sleytr \& Messner, 1992). The most detailed self-assembly and reattachment experiments have been performed with Slayers from the Bacillaceae. S-layers from these organisms reveal a high anisotropic charge distribution, the inner surface being net negatively charged due to an excess of carboxylic acid groups, whereas the outer surface is neutral due to an equimolar amount of carboxylic acid and amino groups (Pum \& Sleytr, 1996). This appears to be essential for proper orientation during local insertion in the course of lattice growth (Sleytr \& Messner, 1992). Sleytr et al. (1994) found that synthetic and biological lipid membranes maintained their structural and functional integrity for a much longer period of time when S-layers were used as supporting structures (Pum \& Sleytr, 1994; Pum et al., 1993). An identical crystalline pattern of $S$-layers can be observed upon reconstitution on solid supports such as carbon polymers, silica, glass, mica, metals, etc. (Pum \& Sleytr, 1993; Sleytr et al., 1992). Large-scale recrystallized S-layers were used as a supporting and stabilizing structure for Langmuir-Blodgett films and reconstituted biological membranes (Pum \& Sleytr, 1994, 1993; Pum et al., 1993). S-layer proteins isolated from B. coagulans E38-66 can be recrystallized into large-scale coherent monolayers at an air-water interface on phospholipid films spread on a Langmuir-Blodgett trough (Pum \& Sleytr, 1996; Pum et al., 1993). Structural analysis of in vitro self-assembly products have shown that in double S-layers, two identical layers can be linked in a minor symmetric fashion (Sleytr et al., 1992). Isolated S-layer (a)

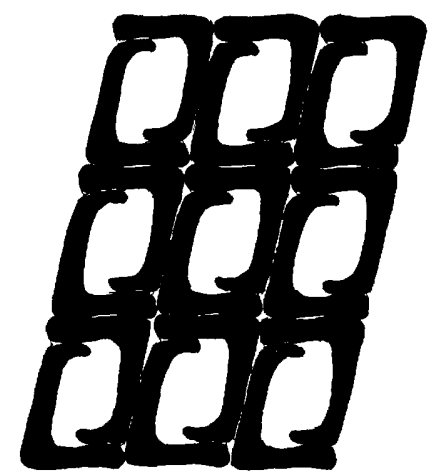

(b)

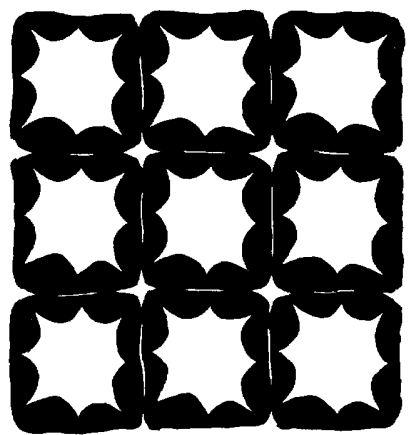

(c)

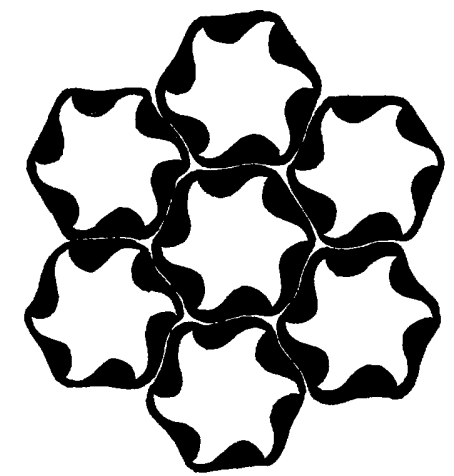

Fig. 2. Schematic drawing of the most common types of S-layer lattices observed in Bacillus species. (a) Oblique (p2) lattice, (b) square (p4) lattice, (c) hexagonal (p6) lattice. (Modified from Sleytr \& Messner, 1992.) 
subunits from the wild-type strain of $B$. stearothermophilus reassembled into distint types of cylindrical and sheet-like self-assembly products correlated with the presence of mono- or bivalent cations during dialysis (Pum et al., 1989; Messner et al., 1986). Chemical analysis of peptidoglycans containing sacculi, and extraction and recrystallization experiments revealed that the wild-type strain $B$. stearothermophilus PV72 had a cell-wall polymer consisting of $\mathrm{N}$-acetylglucosamine and glucose, which are responsible for binding the p6 Slayer protein to the rigid cell wall layer (Sára et al., 1996).

\section{Adsorption}

In comparison with S-layer-deficient strains, S-layercarrying members of the Bacillaceae adsorb much more readily to positively charged or hydrophobic surfaces (Sára et al., 1992; Sleytr \& Messner, 1992; unpublished observations). The adsorption properties for protein moleculesstrongly depended on the charge and hydrophobicity of attached nucleophiles (Küpcü et al., 1993, 1991). In addition, a direct relationship was observed between the molecular dimensions of attached nucleophiles and pore size reduction. This was expressed in significant changes in rejection characteristics (Küpcü $e t$ al., 1993). Adsorption studies by Sára et al. (1992) demonstrated that free amino and carboxyl groups exposed on the outer surface of the native S-layer lattice, and in the interior of the pores, are directly neutralized by electrostatic interactions, leading to a charge-neutral surface in the pore areas. In B. coagulans E38-66, the Slayer lattice masks the net negative surface of the peptidoglycan and prevents nonspecific adsorption of macromolecules, which can be essential requirements to prevent pore plugging and to maintain an unhindered transport of low-molecular-mass substances (nutrients and metabolites) and secretion of exoproteins (Sára et al., 1992; Pum et al., 1989; Sára \& Sleytr, 1987b). Egelseer et al. (1995) concluded that the S-layer proteins from B. stearothermophilus DSM 2358 function as an adhesion site for a high-molecular-mass amylase. Slayers in Bacillaceae act as specific sites for phage adsorption. The crystalline arrays were present on all the 24 phage-resistant mutants of B. sphaericus $\mathrm{P}-1$, although the molecular mass of the S-layer subunits had changed in many mutants (Sleytr \& Messner, 1992). A mutant strain of $B$. brevis $47-52$ was isolated as a phageresistant colony having a two-layered cell wall consisting of the middle and inner wall layers and containing only a $150000 \mathrm{Da}$ protein as the major cell-wall protein (Tsuboi et al., 1982). Removal of the protease-sensitive domain from the S-layer protein of B. sphaericus resulted in the inability to adsorb to the cell walls but did not destroy the capacity for macromolecular assembly (Hastie \& Brinton, 1979a). Adsorption, structural labelling and chemical modification studies revealed that the S-layer lattice from B. coagulans E38-66 is a highly specialized supramolecular structure in possessing (a) anisotropic topographical and physicochemical surface properties (Sleytr \& Messner, 1992; Pum et al., 1989), (b) very precise molecular-sieving properties, with charge-neutral pores preventing unspecific adsorption (Sára \& Sleytr, 1993; Sleytr \& Messner, 1992; Sára et al., 1992), (c) a charge-neutral characteristic of the more elevated domains on the outer surface ( Sára \& Sleytr, 1993; Pum et al., 1989), (d) a net negatively charged inner S-layer capable of binding to the net negatively charged peptidoglycan-containing layer (Sára \& Sleytr, 1993), and (e) an outer surface more hydrophobic than the inner surface (Pum et al., 1993).

\section{Specific functions of S-layers}

Although there is strong evidence that crystalline arrays have the potential to function as protective coats, the $S$ layers from thermophilic members of the family Bacillaceae studied so far cannot be considered as such. Studies by Sára et al. (1990) showed that the S-layers of two of the eight mesophilic members of the Bacillaceae (B. circulans CCM 2048, and B. brevis strains CCM 1089 and CCM 1463), do not act as a protective layer. Whole cells from these three mesophilic species were rapidly lysed by the muramidase lysozyme (molecular mass $14600 \mathrm{Da}$ ) and mutanolysin (molecular mass $24000 \mathrm{Da}$ ). This showed that S-layers possessing pores larger than $3.5 \mathrm{~nm}$ in size allow free passage for both these enzymes (Sára et al., 1990). It has been suggested that S-layers from some members of the Bacillaceae can protect the peptidoglycan from muramidases and the protoplast from proteases (Sleytr \& Messner, 1983), but not in the case of B. stearothermophilus (Egelseer et al., 1995). S-layers possess pores with sizes of $4^{-}-5 \mathrm{~nm}$ which allow the passage of proteins with a molecular mass of up to $45000 \mathrm{Da}$ (Sára \& Sleytr, 1987a), including neuraminidases and proteases (Sleytr \& Messner, 1983). S-layers with pores of this size cannot be considered effective protective barriers (Sára et al., 1992). For a few Bacillus species it has been demonstrated that lysozyme resistance is related to a modified peptidoglycan layer, but does not result from smaller pores in their S-layer lattices (Sára et al., 1994, 1990). Among 39 strains of $B$. stearothermophilus possessing S-layers with different structures, not a single strain was found to be insensitive to lysozyme, indicating that channels with diameters larger than $3 \mathrm{~nm}$ (Stryer, 1975) are present in the lattices (Messner et al., 1984). A wild-type strain of B. stearothermophilus, and both variant $3 \mathrm{a} / \mathrm{V} 1$ and $3 \mathrm{a} / \mathrm{V} 2$ were sensitive to the chosen muramidase, indicating that in all S-layer types the pores are large enough for passage of proteins with molecular masses of at least $24000 \mathrm{Da}$ (Messner et al., 1984). S-layer-carrying B. stearothermophilus strains can produce large amounts of exoprotein with molecular masses above the exclusion limit of their S-layer (Archibald, 1989). The involvement of lattices in exoprotein secretion has yet to be examined. It has been suggested that S-layers from members of the Bacillaceae can delineate a kind of periplasmic space in their cell envelopes (Sturm et al., 1993; Breitwieser et al., 1992). Computer image reconstruction of S-layers from several thermophilic Bacillus strains revealed two types of pores differing in size and morphology (Sára et al., 1994; Pum 
et al., 1989; Messner et al., 1986). Different pores in the lattices may have different functions (Sára et al., 1992). One of the pore types may guarantee unhindered passage of nutrients, whereas the other type may play an important role in exoenzyme secretion. B. stearothermophilus revealed sharp exclusion limits for molecules with molecular masses larger than $45000 \mathrm{Da}$, including a limiting pore diameter of about $4.5 \mathrm{~nm}$ in the crystalline meshwork (Egelseer et al., 1995; Sleytr \& Messner, 1992). In some mesophilic Bacillus species, a pore size as small as $2.5 \mathrm{~nm}$ has been determined (Sleytr \& Messner, 1992).

\section{S-layers and virulence}

S-layers have been found in pathogenic Bacillus species and many other pathogenic bacteria (Sleytr \& Messner, $1988 \mathrm{~b})$. Their presence may be required for an infection to occur (Smith, 1986; Ishigura et al., 1981). It has been suggested that S-layers are important virulence factors in pathogenic bacteria, protecting against complement killing, facilitating binding of the bacterium to host molecules or enhancing its ability to associate with macrophages (Sleytr et al., 1993). The S-layer may have an important function in linking the capsule to the peptidoglycan layer and controlling the exchange of molecules with the environment. $B$. thuringiensis is distinguished from $B$. cereus by the production in the cell of a protein parasporal crystal. The ability to synthesize the parasporal crystals is plasmid-encoded (Ward \& Ellar, 1987). Authentic cultures of B. cereus can acquire the ability to produce crystals following growth in mixed culture with B. thuringiensis (Gonzalez et al., 1982). Smith et al. (1993) described some immunological effects of oligosaccharide-S-layer conjugates isolated from $B$. stearothermophilus NRS 2004/3a, PV72, B. alvei CCM205 and Clostridium thermobydrosulfuricum L111-69. S-layers have the intrinsic property of assembling into large two-dimensional arrays (Messner \& Sleytr, 1992; Sleytr \& Messner, 1983; Sleytr, 1978) and produce effective antigenic aggregates which correspond to those produced by mixing conventional carrier protein conjugates with adjuvants such as aluminium hydroxide (Smith et al., 1993). The suitability of S-layers as carriers/adjuvants for the production of conjugate vaccines has been described (Malcolm et al., 1993a, b; Smith et al., 1993). In conjugate vaccines, haptens are bound to a protein by covalent linkages and, due to the crystalline nature of Slayer proteins or glycoproteins, the functional groups available for hapten-binding are present on each protomer in identical positions and orientations. Hapten-Slayer conjugates function as immunogens without the need for extraneous adjuvants (Smith et al., 1993; Messner et al., 1992).

\section{Genetic studies}

Molecular cloning and characterization of the genes encoding S-layer proteins and glycoproteins are important for elucidation of the mechanisms involved in their biosynthesis, translocation across membranes, assembly at the external cell surface and the precise biological properties of these macromolecules. Studies of the genetics and secretion of S-layers have been shown to be most relevant for recombinant DNA technology. Genetic studies on S-layer proteins demonstrated that most genes encoding these proteins exist as single copies on the genome (Messner \& Sleytr, 1992). The DNA fragments of the protein-producing $B$. brevis 47 were first cloned into Escherichia coli and B. subtilis (Yamagata et al., 1987; Tsukagoshi et al., 1984). The complete nucleotide sequence of the OWP (outer-wall protein) gene of $B$. brevis 47 was determined by Tsuboi et al. (1986). A portion of each of the OWP and MWP (middle-wall protein) genes of $B$. brevis 47 was cloned in E. coli by an immunological procedure (Tsukagoshi et al., 1984). Analysis of transcripts in B. brevis 47 revealed that the genes for the MWP and OWP constitute a cotranscriptional unit and they are transcribed from multiply and tandemly arranged promoters located upstream of the MWP gene [cwp (cell-wall protein gene) operon] (Yamagata et al., 1987; Tsuboi et al., 1986). After analysis of the DNA sequence of the promoter region (Yamagata et al., 1987), the complete nucletide sequence of the $c w p$ operon was determined (Tsuboi et al., 1988). Different promoters were used in B. brevis 47 at different stages of growth and they play distinct roles in growth-phase-specific expression of the cell-wall proteins (Adachi et al., 1989). The MWP gene has two tandemly located translation initiation sites. Both of them can be utilized to start translation in B. brevis 47 , resulting in two different !eader sequences (Adachi et al., 1990). Conserved structures of cell-wall protein genes in different S-layer-protein-producing $B$. brevis strains were investigated to determine the complex organization of the regulatory regions of these genes (Ebisu et al., 1990). B. brevis HPD 31 contains a hexagonally arranged S-layer protein (HWP) and the gene encoding this protein was cloned and sequenced. Analysis of the DNA sequence revealed that there is an open reading frame encoding a polypeptide of 1087 amino acid residues with a molecular mass of $123456 \mathrm{Da}$. The deduced amino acid sequence of the protein showed a high degree of homology $(78 \%)$ with that of $B$. brevis 47 . For amino acid residues 1-548, the homology was $90 \%$ (Gruber $e t$ al., 1988). The complete nucleotide sequence of the Slayer protein gene ( $s b s A)$ of $B$. stearothermophilus PV72 has been studied; after comparison with that of other species it was concluded that the amino acid similarity of S-layer proteins is weak (Kuen \& Lubitz, 1996; Kuen et al., 1994). A domain from residue 27 to approximately residue $200(18 \mathrm{kDa})$ is defined by sequence homology to the OWP of B. brevis. A $4251 \mathrm{bp}$ DNA fragment containing the gene for the S-layer glycoprotein of B. sphaericus 2362 was cloned into $E$. coli encoding a protein with 1176 amino acid residues (Bowditch et al., 1989). Ochterlony immunodiffusion experiments, sequence identity of the $\mathrm{N}$-termini of these molecules and antibody reaction suggested that the $S$ layer protein of B. sphaericus 2362 serves as a precursor of the $110 \mathrm{kDa}$ larvicidal protein, which appears during 
sporulation (Bowditch et al., 1989). The gene encoding the non-glycosylated, hexagonally arranged S-layer of $B$. stearothermophilus PV72 was cloned and sequenced by Kuen et al. (1994). These authors showed sequence comparisons with other signal sequences and found a high degree of homology within signal sequences of extracellular proteins in Bacillus species, such as alkaline phosphatase and neutral protease from B. amyloliquefaciens (Vasantha et al., 1984), as well as the signal sequence for B. sphaericus gene 125 (Bowditch et al., 1989), and the outer-wall protein gene for B. brevis (Tsuboi et al., 1986). Peptide mapping and N-terminal sequencing results strongly indicated that the S-layer protein of B. stearothermophilus NRS 2004/3a and two induced variant strains are encoded by different genes and are not derived from a universal precursor form (Sára et al., 1994). The results from Southern hybridization indicated that chromosomal rearrangement is responsible for S-layer protein variation in B. stearothermophilus PV72 (Sára et al., 1996, 1994; Sára \& Sleytr, 1994). The gene encoding the S-layer protein was cloned from a B. licheniformis NM105 gene library and was expressed in E. coli NM539 and JM109 and B. subtilis MI112 (pMK462) (Tang et al., 1989). In $B$. brevis, Tsukagoshi et al. (1984) observed that transferred cells of E. coli JM539 produced only a truncated polypeptide $(75 \mathrm{kDa})$, while the $S$-layer protein expressed in B. subtilis MI112 had the same molecular mass as the authentic protein purified from $B$. licheniformis NM105 (Tang et al., 1989).

\section{References}

Abe, M. \& Kimoto, N. (1984). Distribution of two types of regulararray particles in the cell wall of Bacillus aneurinolyticus (Kimura et Aoyama). Microbiol Immunol 28, 841-846.

Abe, M., Kimoto, M. \& Yoshii, Z. (1983). Structural and chemical characterization of macromolecular arrays in the cell wall of Bacillus brevis S1. FEMS Microbiol Lett 18, 263-267.

Adachi, T., Yamagata, H., Tsukagoshi, N. \& Udaka, S. (1989). Multiple and tandemly arranged promoters of the cell wall protein gene operon in Bacillus brevis 47. J Bacteriol 171, 1010-1016.

Adachi, T., Yamagata, H., Tsukagoshi, N. \& Udaka, S. (1990). Use of both translation initiation sites of the middle wall protein gene in Bacillus brevis 47. J Bacteriol 172, 511-513.

Aebi, U., Smith, P. R., Dubochet, J., Henry, C. \& Kellenberger, E. (1973). A study of the structure of the T-layer of Bacillus brevis. J Supramol Struct 1, 498-522.

Altman, E., Brisson, J.-R., Messner, P. \& Sleytr, U. B. (1991). Structure of the glycan chain from the surface layer glycoprotein of Bacillus alvei CCM 2051. Biochem Cell Biol 69, 72-78.

Archibald, R. (1989). The Bacillus cell envelope. In Bacillus Biotechnology Handbook, vol. 2, pp. 217-254. Edited by C. R. Harwood. New York: Plenum Press.

Aronson, A. I. (1993). Insecticidal toxins. In Bacillus subtilis and Other Gram-positive Bacteria: Biochemistry, Physiology and Molecular Genetics, pp. 953-963. Edited by A. L. Sonenshein, J. A. Hoch \& R. Losick. Washington, DC: American Society for Microbiology.
Baumeister, W. \& Engelhardt, H. (1987). Three-dimensional structure of bacterial surface layers. In Electron Microscopy of Proteins, vol. 6, pp.109-154. Edited by R. Harris \& R. W. Horne. London: Academic Press.

Baumeister, W., Barth, M., Hegerl, R., Guckenberger, R., Hahn, M. \& Saxton, W. O. (1986). The three-dimensional structure of the regular surface layer (HPI layer) of Deinococcus radiodurans. $J$ Mol Biol 187, 241-253.

Beecher, D. J. \& Macmillan, J. D. (1991). Characterization of the components of hemolysin BL from Bacillus cereus. Infect Immun 59, 1778-1784.

Beveridge, T. J. (1979). Surface arrays on the wall of Sporosarcina ureae. J Bacteriol 139, 1039-1048.

Beveridge, T. J. (1981). Ultrastructure, chemistry and function of the bacterial wall. Int Rev Cytol 72, 229-317.

Beveridge, T. J. (1994). Bacterial S-layers. Curr Opin Struct Biol 4, 202-212.

Beveridge, T. J. \& Graham, L. L. (1991). Surface layers of bacteria. Microbiol Rev 55, 684-705.

Beveridge, T. J. \& Koval, S. F. (1993). Advances in Bacterial Paracrystalline Surface Layers. New York: Plenum Press.

Beveridge, T. J., Popkin, T. J. \& Cole, R. M. (1994). Electron microscopy. In Methods for General and Molecular Bacteriology, pp. 42-71. Edited by P. Gerhardt, R. G. E. Murray, W. A. Woods $\&$ N. R. Krieg. Washington, DC: American Society for Microbiology.

Bowditch, R. D., Baumann, P. \& Yousten, A. A. (1989). Cloning and sequencing of the gene encoding a 125 -kilodalton surfacelayer protein from Bacillus sphaericus 2362 and of a related cryptic gene. J Bacteriol 171, 4178-4188.

Breitwieser, A., Gruber, K. \& Sleytr, U. B. (1992). Evidence for an S-layer pool in peptidoglycan of Bacillus stearothermophilus. $J$ Bacteriol 174, 8008-8015.

Broadwell, A. H. \& Baumann, P. (1986). Sporulation-associated activation of Bacillus sphaericus larvicide. Appl Environ Microbiol 52, 758-764.

Burley, S. K. \& Murray, R. G. E. (1983). Structure of the regular surface layer of Bacillus polymyxa. Can J Microbiol 29, 775-780.

Christian, R., Schultz, G., Unger, F. M., Messner, P., Küpcu, Z. \& Sleytr, U. B. (1986). Structure of a rhamnan from the surface layer glycoprotein of Bacillus stearothermophilus strain NRS 2004/3a. Carbohydr Res 150, 265-272.

Daugulis, A. J., Whitney, G. K., Wong, A. \& Wight, C. P. (1993). Scale-up of S-layer protein secretion by Bacillus brevis 47 . In Advances in Bacterial Paracrystalline Surface Layers, pp. 235-241. Edited by T. J. Beveridge \& S. F. Koval. New York: Plenum Press.

Dooley, J. S., McCubbin, W. D., Kay, C. M. \& Trust, T. J. (1988). Isolation and biochemical characterization of the $S$-layer protein from a pathogenic Aeromonas hydrophila strain. J Bacteriol 170, 2631-2638.

Doyle, R. J., Beveridge, T. J., Stewart, M. \& Ezzell, J. W. (1986). Evidence for a surface array on Bacillus anthracis. In Abstracts of the 86th Annual Meeting of the American Society for Microbiology, abstract J-18, p. 191. Washington, DC: American Society for Microbiology.

Drobniewski, F. A. (1993). Bacillus cereus and related species. Clin Microbiol Rev 6, 324-338.

Ebisu, S., Tsuboi, A., Takagi, H., Naruse, Y., Yamagata, H., 
Tsukagoshi, N. \& Udaka, S. (1990). Conserved structures of cell wall protein genes among protein-producing Bacillus brevis strains. J Bacteriol 172, 1312-1320.

Egelseer, E., Schocher, I., Sára, M. \& Sleytr, U. B. (1995). The Slayer from Bacillus stearothermophilus DSM 2358 functions as adhesion site for a high-molecular-weight amylase. $J$ Bacteriol 177, 1444-1451.

Ellar, D. \& Lundgren, D. G. (1967). Ordered substructure in the cell wall of Bacillus cereus. J Bacteriol 94, 1778-1780.

Engelhardt, H., Saxton, W. O. \& Baumeister, W. (1986). Threedimensional structure of the tetragonal surface layer of Sporosarcina ureae. J Bacteriol 168, 309-317.

Farchaus, J. W., Ribot, W. J., Downs, M. B. \& Ezzell, J. W. (1995). Purification and characterization of the major surface array protein from the avirulent Bacillus anthracis dalta sterne-1. I Bacteriol 177, 2481-2489.

Finch, J. T., Klug, A. \& Nermut, M. V. (1967). The structure of the macromolecular units on the cell wall of Bacillus polymyxa.J Cell Sci 2, 587-590.

Gerhardt, P. (1967). Cytology of Bacillus anthracis. Fed Proc 26, 1504-1517.

Gonzalez, J. M., Jr, Brown, B. S. \& Carlton, B. C. (1982). Transfer of Bacillus thuringiensis plasmid coding for $\delta$-endotoxin among strains of Bacillus thuringiensis and Bacillus cereus. Proc Natl Acad Sci USA 79, 6951-6955.

Goundry, J., Archibald, A. R., Baddiley, J. \& Davison, A. L. (1967). The structure of the cell wall of Bacillus polymyxa NCIB 4747. Biochem J 104, 1-3.

Gruber, K. \& Sleytr, U. B. (1988). Localized insertion of new Slayer during growth of Bacillus stearothermophilus strains. Arch Microbiol 149, 485-491.

Gruber, K., Tanahashi, H., Tsuboi, A., Tsukogoshi, N. \& Udaka, S. (1988). Comparative study on the cell wall structure of protein producing Bacillus brevis. FEMS Microbiol Lett 56, 113-118.

Haapasalo, M., Lounatmaa, K. \& Ranta, H. (1988). Paracrystalline surface layer of a novel Bacillus sp. M3198. In Crystalline Bacterial Cell Surface Layers, pp. 92-95. Edited by U. B. Sleytr, P. Messner, D. Pum \& M. Sára. Berlin: Springer.

Hartmann, E., Messner, P., Allmeier, G. \& König, H. (1993). Proposed pathway for biosynthesis of the S-layer glycoprotein of Bacillus alvei. J Bacteriol 175, 4515-4519.

Hastie, A. T. \& Brinton, C. C., Jr (1979a). Isolation, characterization and in vitro assembly of the tetragonally arrayed layers of Bacillus sphaericus. J Bacteriol 138, 999-1009.

Hastie, A. T. \& Brinton, C. C., Jr (1979b). Specific interaction of the tetragonally arrayed protein layer of Bacillus sphaericus with its peptidoglycan sacculus. J Bacteriol 138, 1010-1021.

Holt, S. C. \& Leadbetter, E. R. (1969). Comparative ultrastructure of selected aerobic spore-forming bacteria: a freeze-etching study. Bacteriol Rev 33, 346-378.

Hovmöller, S., Sjögren, A. \& Wang, D. N. (1988). The structure of crystalline bacterial surface layers. Prog Biophys Mol Biol 51, 131-163.

Howard, L. V. \& Tipper, D. J. (1973). A polypeptide bacteriophage receptor: modified cell wall protein subunits in bacteriophageresistant mutants of Bacillus sphaericus strain P-1. J Bacteriol 113, 1491-1504.

Howard, L. V., Dalton, D. D. \& MacCoubrey, W. K. (1982). Expansion of the tetragonally arrayed cell wall protein layer during growth of Bacillus sphaericus. J Bacteriol 149, 748-757.
Howatson, A. F. \& Russell, W. C. (1964). Observations on cell wall structure in Bacillus subtilis. J Appl Physiol 35, 3086-3087.

Ishigura, E. E., Kay, W. W., Ainsworth, T., Chamberlain, J. B., Austen, R. A., Buckley, J. T. \& Trust, T. J. (1981). Loss of virulence during culture of Aeromonas salmonicida at high temperature. $J$ Bacteriol 148, 333-340.

Jaenicke, R., Welsch, R., Sára, M. \& Sleytr, U. B. (1985). Stability and self-assembly of the $S$-layer protein of the cell wall of Bacillus stearothermophilus. Biol Chem Hoppe-Seyler 366, 663-670.

Kari, M., Rónkkő, R., Valtonen, A., Piiparinen, H., Kukkonen, M., Pöyry, T., Nohynek, L., Nurmiaho-Lassila, E.-L. \& Lounatmaa, K. (1990). Ultrastructure of a Bacillus sp. strain KL8 isolated from indoor dust. J Basic Microbiol 30, 99-104.

Kónig, H. (1988). Archeobacterial cell envelopes. Can J Microbiol 33, 395-406.

Kosma, P., Neuninger, C., Christian, R., Schulz, G. \& Messner, P. (1995). Glycan structure of the $S$-layer glycoprotein of Bacillus sp. L420-91. Glycoconj J 12, 99-107.

Kotiranta, A., Haapasalo, M., Lounatmaa, K. \& Kari, K. (1995). Crystalline surface protein of Peptostreptococcus anaerobius. Microbiology 141, 1065-1073.

Koval, S. F. (1988). Paracrystalline protein surface arrays on bacteria. Can J Microbiol 34, 407-414.

Koval, S. F. (1993). Predation on bacteria possessing S-layers. In Advances in Bacterial Paracrystalline Surface Layers, pp. 85-92. Edited by T. J. Beveridge \& S. F. Koval. New York: Plenum Press.

Koval, S. F. \& Murray, R. G. E. (1986). The superficial protein arrays on bacteria. Microbiol Sci 3, 357-361.

Kuen, B. \& Lubitz, W. (1996). Analysis of S-layer proteins and genes. In Crystalline Bacterial Cell Surface Proteins, pp. 77-102. Edited by U. B. Sleytr, P. Messner, D. Pum \& M. Sára. London: Academic Press.

Kuen, B., Sleytr, U. B. \& Lubitz, W. (1994). Sequence analysis of the $s b s A$ gene encoding the $130 \mathrm{kDa}$ surface layer protein of Bacillus stearothermophilus PV72. Gene 145, 115-120.

Kupcu, Z., Marz, L., Messner, P. \& Sleytr, U. B. (1984). Evidence for the glycoprotein nature of the crystalline cell wall layer of Bacillus stearothermophilus strain NRS 2004/3a. FEBS Lett 173, 185-190.

Küpcủ, S., Sára, M. \& Sleytr, U. B. (1991). Chemical modification of crystalline ultrafiltration membranes and immobilization of macromolecules. J Membr Sci 61, 167-175.

Küpcu, S., Kuen, B., Sára, M. \& Sleytr, U. B. (1993). Influence of covalent attachment of low molecular weight substances on the rejection and adsorption properties of crystalline proteinaceous ultrafiltration membranes. Desalination 90, 65-76.

Leduc, M., Rousseau, M. \& van Heijenoort, J. (1977). Structure of the cell wall of Bacillus species C. I. P. 76-111. Eur J Biochem 80, 153-163.

Lepault, J., Martin, N. \& Leonard, K. (1986). Three-dimensional structure of the T-layers of Bacillus sphaericus P-1. J Bacteriol 168, 303-308.

Lewis, L. O., Yousten, A. A. \& Murray, R. G. E. (1987). Characterization of surface protein layers of the mosquito-pathogenic strains of Bacillus sphaericus. J Bacteriol 169, 72-79.

Luckevich, M. D. \& Beveridge, T. J. (1989). Characterization of a dynamic S-layer on Bacillus thuringiensis. J Bacteriol 171, 6656-6667.

Lupas, A., Engelhardt, H., Peters, J., Santarius, U., Volker, S. \& Baumeister, W. (1994). Domain structure of the Acetogenium 
kivui surface layer revealed by electron crystallography and sequence analysis. J Bacteriol 176, 1224-1233.

Maiden, F. J., Lai, C.-H. \& Tanner, A. (1992). Characteristics of oral gram positive bacteria. In Contemporary Oral Microbiology and Immunology, pp. 342-372. Edited by J. Slots \& M. A. Taubman. St Louis: Mosby Year Book.

Malcolm, A. J., Best, M. W., Szarka, R. J., Mosleh, Z., Unger, F. M., Messner, P. \& Sleytr, U. B. (1993a). Surface layers from Bacillus alvei as a carrier for a Streptococcus pneumoniae conjugate vaccine. In Advances in Bacterial Paracrystalline Surface Layers, pp. 219-233. Edited by T. J. Beveridge \& S. F. Koval. New York: Plenum Press.

Malcolm, A. J., Messner, P., Sleytr, U. B., Smith, R. H. \& Unger, F. M. (1993b). Crystalline bacterial cell surface layers (S-layers) as combined carrier/adjuvants for conjugate vaccines. In Immobilized Macromolecules: Application Potentials, pp. 195-207. Edited by U. B. Sleytr, P. Messner, D. Pum \& M. Sára. London: Springer.

Masuda, K. \& Kawata, T. (1979). Ultrastructure and partial characterization of a regular array in the cell wall of Lactobacillus brevis. Microbiol Immunol 23, 941-953.

Messner, P. \& Sleytr, U. B. (1991). Bacterial surface layer glycoproteins. Glycobiol 1, 545-551.

Messner, P. \& Sleytr, U. B. (1992). Crystalline bacterial cell surface layers. Adv Microb Physiol 33, 213-275.

Messner, P., Hollaus, F. \& Sleytr, U. B. (1984). Paracrystalline cell wall surface layers of different Bacillus stearothermophilus strains. Int J Syst Bacteriol 34, 202-210.

Messner, P., Pum, D. \& Sleytr, U. B. (1986). Characterization of the ultrastructure and the self-assembly of surface layers of Bacillus stearothermophilus strain NRS 2004/3a. J Ultrastruct Mol Struct Res 97, 73-88.

Messner, P., Sleytr, U. B., Christian, R., Schultz, G. \& Unger, F. M. (1987). Isolation and structure determination of a diacetamidodideoxyuronic acid-containing glycan chain from the S-layer glycoprotein of Bacillus stearothermophilus NRS 2004/3a. Carbobydr Res 168, 211-218.

Messner, P., Mazid, M. A., Unger, F. M. \& Sleytr, U. B. (1992). Artificial antigens. Synthetic carbohydrate haptens immobilized on crystalline bacterial surface layer glycoproteins. Carbobydr Res 233, 175-184.

Nermut, M. V. \& Murray, R. G. E. (1967). Ultrastructure of the cell wall of Bacillus polymyxa. J Bacteriol 93, 1949-1965.

Ohnesorge, F., Heckl, W. M., Häberle, W. \& 8 other authors (1992). Scanning force microscopy studies of the S-layers from Bacillus coagulans E38-66, Bacillus sphaericus CCM2177 and of an antibody binding process. Ultramicroscopy 42, 1236-1242.

Pum, D. \& Sleytr, U. B. (1993). Molecular nanotechnology with Slayers. In Advances in Bacterial Paracrystalline Surface Layers, pp. 195-204. Edited by T. J. Beveridge \& S. F. Koval. New York: Plenum Press.

Pum, D. \& Sleytr, U. B. (1994). Large scale reconstitution of crystalline bacterial surface layer (S-layer) proteins at the air/ water interface and on lipid films. Thin Solid Films 244, 882-886.

Pum, D. \& Sleytr, U. B. (1996). Molecular nanotechnology and biomimetics with S-layers. In Crystalline Bacterial Cell Surface Proteins, pp. 175-209. Edited by U. B. Sleytr, P. Messner, D. Pum \& M. Sára. London: Academic Press.

Pum, D., Sára, M. \& Sleytr, U. B. (1989). Structure surface-charge and self-assembly of the S-layer lattice of Bacillus coagulans E3666. J Bacteriol 171, 5296-5303.

Pum, D., Weinhandl, M., Hodl, C. \& Sleytr, U. B. (1993). Large- scale recrystallization of the S-layer of Bacillus coagulans E38-66 at the air/water interface and on lipid films. J Bacteriol 175, 2762-2766.

Sára, M. \& Sleytr, U. B. (1987a). Production and characteristics of ultrafiltration membranes with uniform pores from two dimensional array proteins. J Membr Sci 33, 27-49.

Sára, M. \& Sleytr, U. B. (1987b). Molecular sieving through Slayers of Bacillus stearothermophilus strains. J Bacteriol 169, 4092-4098.

Sára, M. \& Sleytr, U. B. (1993). Relevance of charged groups for the integrity of the S-layer from Bacillus coagulans E38-66 and for molecular interactions. J Bacteriol 175, 2248-2254.

Sára, M. \& Sleytr, U. B. (1994). Comparative studies of S-layer proteins from Bacillus stearothermophilus strains expressed during growth in continuous culture under oxygen-limited and non-oxygen-limited conditions. J Bacteriol 176, 7182-7189.

Sára, M., Moser-Thier, K., Kainz, U. \& Sleytr, U. B. (1990). Characterization of S-layers from mesophilic Bacillaceae and studies on their protective role towards muramidases. Arch Microbiol 153, 209-214.

Sára, M., Pum, D. \& Sleytr, U. B. (1992). Permeability and chargedependent adsorption properties of the S-layer lattice from Bacillus coagulans E36-66. J Bacteriol 174, 3487-3493.

Sára, M., Küpcu, S., Weiner, C., Weigert, S. \& Sleytr, U. B. (1993a). Crystalline protein layers as isoporous molecular-sieves and immobilization and affinity matrices. In Immobilized Macromolecules: Application Potentials, pp. 71-86. Edited by U. B. Sleytr, P. Messner, D. Pum \& M. Sára. London: Springer.

Sára, M., Küpcu, S., Weiner, C., Weigert, S. \& Sleytr, U. B. (1993b). $S$-layers as immobilization and affinity matrix. In Advances in Bacterial Paracrystalline Surface Layers, pp. 195-204. Edited by T. J. Beveridge \& S. F. Koval. New York: Plenum Press.

Sára, M., Pum, D., Küpcu, S., Messner, P. \& Sleytr, U. B. (1994). Isolation of two physiological induced variant strains of Bacillus stearothermophilus NRS 2004/3a and characterization of their Slayer lattices. J Bacteriol 176, 848-860.

Sára, M., Kuen, B., Mayer, H. F., Mandl, F., Schuster, K. C. \& Sleytr, U. B. (1996). Dynamics in oxygen-induced changes in S-layer protein synthesis from Bacillus stearothermophilus PV72 and the S-layer-deficient variant T5 in continuous culture and studies of the cell wall composition. J Bacteriol 178, 2108-2117.

Sawatake, M. (1966). Macromolecular crystal-like arrays found in the cell wall of disrupted Bacillus megaterium. Proceedings of the 6th International Congress of Electron Microscopy, Kyoto, vol. 2, pp. 279-280. Tokyo: Maruzen.

Schenk, A. \& Aragno, N. (1979). Bacillus schlegelii, a new species of thermophilic, facultatively chemolithoautotrophic bacterium oxidizing molecular hydrogen. J Gen Microbiol 115, 333-341.

Sleytr, U. B. (1976). Self-assembly of the hexagonally and tetragonally arranged subunits of bacterial surface layers and their reattachment to cell walls. J Ultrastruct Res 55, 360-377.

Sleytr, U. B. (1978). Regular arrays of macromolecules on bacterial cell walls: structure, chemistry, assembly and function. Int Rev Cytol 53, 1-64.

Sleytr, U. B. \& Glauert, A. M. (1975). Analysis of regular arrays of subunits on bacterial surfaces: evidence for a dynamic process of assembly. J Ultrastruct Res 50, 103-116.

Sleytr, U. B. \& Glauert, A. M. (1976). Ultrastructure of the cell walls of two closely related clostridia that possess different regular arrays of surface subunits. J Bacteriol 126, 869-882.

Sleytr, U. B. \& Messner, P. (1983). Crystalline surface layers of bacteria. Annu Rev Microbiol 37, 311-339. 
Sleytr, U. B. \& Messner, P. (1988a). Crystalline surface layers of procaryotes. J Bacteriol 170, 2891-2897.

Sleytr, U. B. \& Messner, P. (1988b). Crystalline layers on bacteria. In Crystalline Bacterial Cell Surface Layers, pp. 160-186. Edited by U. B. Sleytr, P. Messner, D. Pum \& M. Sára. Berlin: Springer.

Sleytr, U. B. \& Messner, P. (1992). Crystalline bacterial cell surface layers (S-layers). In Encyclopedia of Microbiology, vol. 1, pp. 605-614. London: Academic Press.

Sleytr, U. B. \& Plohberger, R. (1980). The dynamic process of assembly of two dimensional arrays of macromolecules on bacterial cell walls. In Electron Microscopy at Molecular Dimensions, pp. 36-47. Edited by W. Baumeister \& W. Vogell. Berlin: Springer.

Sleytr, U. B. \& Thorne, K. J. I. (1976). Chemical characterization of the regularly arranged surface layers of Clostridium thermosaccharolyticum and Clostridium thermohydrosulfuricum. J Bacteriol 127, 377-383.

Sleytr, U. B., Adam, H. \& Klaushofer, H. (1969). Die Feinstruktur der Zellwand und Cytoplasmamembran von Clostridium nigrificans, dargestellt mit Hilfe der Gefrierätz- und Ultradünnschnittechnik. Arch Mikrobiol 66, 40-58.

Sleytr, U. B., Messner, P., Sára, M. \& Pum, D. (1986a). Crystalline envelope layers in archaeobacteria. Syst Appl Microbiol 7, 310-313.

Sleytr, U. B., Sára, M., Küpcü, Z. \& Messner, P. (1986b). Structural and chemical characterization of S-layers of selected strains of Bacillus stearothermophilus and Desulfotomaculum nigrificans. Arch Microbiol 146, 19-24.

Sleytr, U. B., Messner, P. \& Pum, D. (1988a). Analysis of crystalline bacterial surface layer by freeze-etching, metal shadowing, negative staining and ultrathin sectioning. Methods Microbiol 20, $29-60$.

Sleytr, U. B., Messner, P., Pum, D. \& Sára, M. (1988b). Crystalline Bacterial Cell Surface Layers. Berlin: Springer.

Sleytr, U. B., Pum, D., Sára, M. \& Messner, P. (1992). Twodimensional protein crystals as patterning elements in molecular nanotechnology. In Molecular Electronics: Science and Technology. American Institute of Physics Conference Proceedings, vol. 262, pp. 167-177. Edited by A. Aviram. New York: American Institute of Physics.

Sleytr, U. B., Messner, P., Pum, D. \& Sára, M. (1993). Crystalline bacterial cell surface layers. Mol Microbiol 10, 911-916.

Sleytr, U. B., Sára, M., Messner, P. \& Pum, D. (1994). Application potential of 2D protein crystals (S-layers). Ann NY Acad Sci 745, 261-269.

Sleytr, U. B., Messner, P., Pum, D. \& Sára, M. (1996). Crystalline Bacterial Cell Surface Proteins. London: Academic Press.

Smith, J. (1986). Protein surface layers of bacteria. In Bacterial Outer Membranes as Model Systems, pp. 343-376. Edited by M. Inouye. New York: Wiley.

Smith, R. H., Messner, P., Lamontagne, L. R., Sleytr, U. B. \& Unger, F. M. (1993). Induction of T-cell immunity to oligosaccharide antigens immobilized on crystalline bacterial surface layers ( S-layers). Vaccine 11, 919-924.

Sprott, G. D., Koval, S. F. \& Schnaitman, C. A. (1994). Cell fractionation. In Methods for General and Molecular Bacteriology, pp. 72-103. Edited by P. Gerhardt, R. G. E. Murray, W. A. Woods \& N. R. Krieg. Washington, DC: American Society for Microbiology.

Stewart, M. (1986). Computer analysis of ordered microbiological objects. In Ultrastructure Techniques for Microorganisms, pp.
333-364. Edited by H. C. Aldrich \& W. J. Todd. New York: Plenum Press.

Stewart, M. (1988). An introduction to computer image processing of two-dimensionally ordered biological structures. $J$ Electron Microsc 9, 325-358.

Stewart, M. \& Beveridge, T. J. (1980). Structure of the regular surface layer of Sporosarcina ureae. J Bacteriol 142, 302-309.

Stewart, M., Beveridge, T. J. \& Trust, T. J. (1986). Two patterns in the Aeromonas salmonicida A-layer may reflect a structural transformation that alters permeability. J Bacteriol 166, 120-127.

Stryer, L. (1975). Mechanisms of enzyme action: lysozyme and carboxypeptidase. In Biochemistry, pp. 153-177. San Francisco: Freeman.

Sturm, E., Egeiseer, E., Sára, M. \& Sleytr, U. B. (1993). Can S-layers of Bacillaceae control the release of their own exoproteins? In Advances in Bacterial Paracrystalline Surface Layers, pp. 297-302. Edited by T. J. Beveridge \& S. F. Koval. New York: Plenum Press.

Takagi, H., Kadowaki, K. \& Udaka, S. (1989). Screening and characterization of protein-hyperproducing bacteria without detectable exoprotease activity. Agric Biol Chem 53, 691-699.

Takumi, K., Susami, Y., Takeoka, A., Oka, T. \& Koga, T. (1991). Slayer protein of Clostridium tetani: purification and properties. Microbiol Immunol 35, 569-575.

Tang, M., Owens, K., Pietri, R., Zhu, X., McVeigh, R. \& Ghosh, B. K. (1989). Cloning of the crystalline cell wall protein gene of Bacillus licheniformis NM105. J Bacteriol 171, 6637-6648.

Thorne, C. B. (1993). Bacillus anthracis. In Bacillus subtilis and Other Gram-positive Bacteria: Biochemistry, Physiology and Molecular Genetics, pp. 113-124. Edited by A. L. Sonenshein, J. A. Hoch \& R. Losick. Washington, DC: American Society for Microbiology.

Thorne, K. J. I., Oliver, R. C. \& Glauert, A. M. (1976). Synthesis and turnover of the regularly arranged surface protein of Acinetobacter sp. relative to other components of the cell envelope. $J$ Bacteriol 127, 440-450.

Toumelin, I. E., Sirard, J. C., Dulflot, E., Mock, M. \& Fouet, A. (1995). Characterization of the Bacillus anthracis S-layer : cloning and sequencing of the structural gene. J Bacteriol 177, 614-620.

Tsuboi, A., Tsukagoshi, N. \& Udaka, S. (1982). Reassembly in vitro of hexagonal surface arrays in a protein producing bacterium, Bacillus brevis 47. J Bacteriol 151, 1485-1497.

Tsuboi, A., Uchihi, R., Tabata, R., Takahashi, Y., Hashiba, H., Sasaki, T., Yamagata, H., Tsukagoshi, N. \& Udaka, S. (1986). Characterization of the gene coding for two major cell wall proteins from protein-producing Bacillus brevis 47: complete nucleotide sequence of the outer wall protein gene. $J$ Bacteriol 168, 365-373.

Tsuboi, A., Uchihi, R., Adachi, T., Sasaki, T., Hayakawa, S., Yamagata, H., Tsukagoshi, N. \& Udaka, S. (1988). Characterization of the genes for the hexagonally arranged surface layer proteins in protein-producing Bacillus brevis 47: complete nucleotide sequence of the middle wall protein gene. $J$ Bacteriol 170, 935-945.

Tsuboi, A., Engelhardt, H., Santarius, U., Tsukagoshi, N., Udaka, S. \& Baumeister, W. (1989). Three-dimensional structure of the surface protein layer (MW layer) of Bacillus brevis 47. J Ultrastruct Mol Struct Res 102, 178-187.

Tsukagoshi, N., Tabata, R., Takemura, T., Yamagata, H. \& Udaka, S. (1984). Molecular cloning of major cell wall protein gene from 
protein-producing Bacillus brevis 47 and its expression in Escherichia coli and Bacillus subtilis. J Bacteriol 158, 1054-1060.

Udaka, S. (1976). Screening for protein-producing bacteria. Agric Biol Chem 40, 523-528.

Udaka, S., Tsukagoshi, N. \& Yamagata, H. (1989). Bacillus brevis, a host bacterium for efficient extracelluar production of useful proteins. Biotech Genetics Eng Rev 7, 113-146.

Vasantha, N., Thompson, L. D., Rhodes, C., Banner, C., Nagle, J. \& Filpula, D. (1984). Genes for alkaline protease and neutral protease from Bacillus amyloliquefaciens contain a large open reading frame between the regions coding for signal sequence and mature protein. J Bacteriol 159, 811-819.

Ward, E. S. \& Ellar, D. J. (1987). Nucleotide sequence of a Bacillus thuringiensis var. israelensis gene encoding a $130 \mathrm{kDa}$ deltaendotoxin. Nucleic Acids Res 15, 7195.

Wight, C. P., Whitney, G. K., White, B. N. \& Daugulis, A. J. (1992).
Enhancement and regulation of extracellular protein production by Bacillus brevis 47 through manipulation of cell culture conditions. Biotechnol Bioeng 40, 46.

Word, N. S., Yousten, A. A. \& Howard, L. (1983). Regularly structured and non-regularly structured surface layers of Bacillus sphaericus. FEMS Microbiol Lett 17, 277-282.

Yamada, H., Tsukagoshi, N. \& Ukada, S. (1981). Morphological alterations of the cell wall concomitant with protein release in a protein-producing bacterium, Bacillus brevis 47. J Bacteriol 148, 322-332.

Yamagata, H., Adachi, T., Tsuboi, A., Takao, M., Sasaki, T., Tsukagoshi, N. \& Udaka, S. (1987). Cloning and characterization of the $5^{\prime}$ region of the cell wall protein gene operon in Bacillus brevis 47. J Bacteriol 169, 1239-1245.

Yoshii, Z. (1966). Macromolecular pattern in the cell wall of Bacillus alvei. Proceedings of the 6th International Congress of Electron Microscopy, Kyoto, vol. 2, 227. 